\title{
NIERÓWNOŚCI MAJĄTKOWE NA PRZYKŁADZIE POLSKI I NIEMIEC - WNIOSKI Z BADANIA ZASOBNOŚCI BUDŻETÓW DOMOWYCH
}

\section{Streszczenie}

Cel - Analiza porównawcza poziomu nierówności majątkowych w Polsce i Niemczech. Ich ocena w kontekście realizacji celów społecznej gospodarki rynkowej. Wskazanie potencjalnych czynników wpływających na poziom nierówności majątkowych.

Metodologia badania - Wykorzystano wyniki Badania Budżetów Gospodarstw Domowych (HFCS) prowadzonych cyklicznie w latach 2010-2016 w państwach strefy euro oraz w Polsce i na Węgrzech.

Wynik - Nierówności majątkowe w Niemczech są wyraźnie wyższe niż w Polsce. W przypadku obu krajów czynniki ich wzrostu wydają się być podobne. Wskazuje to na bardzo prawdopodobny w przyszłości wzrost nierówności w Polsce do poziomu obserwowanego u zachodniego sąsiada.

Oryginalność/wartość - Autor wykorzystuje jedyne na ten moment tak obszerne dane dotyczące sytuacji majątkowej gospodarstw domowych. Jednolita metodyka badania umożliwia porównywanie poszczególnych państw między sobą, a cykliczność w realizacji badań umożliwia porównywanie zmian w czasie.

Słowa kluczowe: nierówności ekonomiczne, majątek, dochód, gospodarstwo domowe, HFC

\section{WEALTH INEQUALITIES IN POLAND AND GERMANY - CONCLUSIONS FROM HOUSEHOLD FINANCE AND CONSUMPTION SURVEY}

\section{Summary}

Goal - Comparative analysis of the level of property inequalities in Poland and Germany. Their assessment in the context of achieving the goals of the social market economy. Indication of potential factors affecting the level of property inequalities.

Research methodology - The use of the results of the Household Finance and Consumption Survey (HFCS) conducted cyclically in 2010-2016 in the euro area countries, as well as in Poland and Hungary.

Score - Property inequalities in Germany are higher than in Poland. In the case of both countries, their growth factors seem to be similar. This indicates a very likely future increase in inequalities in Poland to the level observed in the western neighbor.

Originality /value - The author uses the only data available for this moment regarding the wealth situation of households. The uniform methodology of the study makes it possible to 
compare individual countries with one another and cyclicality in the implementation of research enables comparison of changes over time.

Keywords: economics inequalities, wealth, income, household, HFCS

DOI: 10.15290/wpewbmn4.2020.06

\section{Wprowadzenie}

Zgodnie z artykułem 20 Konstytucji Rzeczpospolitej Polskiej za podstawę ustroju gospodarczego Polski uznano społeczną gospodarkę rynkową (SGR). Ma ona być oparta na wolności działalności gospodarczej, własności prywatnej oraz solidarności, dialogu i współpracy partnerów społecznych ${ }^{1}$. Istotą społecznej gospodarki rynkowej jest połączenie równości społecznej i wolności rynkowej².

Przyjęcie przez Polskę w konstytucji zasad SGR jako podstawy ustroju społeczno-gospodarczego jest dowodem uznania dla niemieckiego modelu i wyrazem chęci „powtórzenia” sukcesów zachodniego sąsiada. Sam wzrost gospodarczy nie jest uznany za cel sam w sobie, ale jako środek do celu jakim jest dobrobyt społeczny ${ }^{3}$.

Pozytywna ocena rozwoju gospodarki niemieckiej po II wojnie światowej oznacza również podobną ocenę rozwoju społeczeństwa niemieckiego. Szczególną rolę w tej ocenie mają nierówności ekonomiczne. Jeżeli bowiem uznać wysokie nierówności ekonomiczne (dochodowe i majątkowe) jako dowód na brak spójności ekonomicznej i przyczynę wielu problemów społecznych ${ }^{4}$, to stan tych nierówności w Niemczech powinien być niski, aby ocena rozwoju społecznego mogła być pozytywna. Potwierdzałoby to wówczas potoczną w społeczeństwie polskim opinię o „dobrobycie członków społeczeństwa niemieckiego”.

Pytanie badawcze więc brzmi: „Czy obecny poziom nierówności majątkowych, jaki występuje w społeczeństwie niemieckim potwierdza skuteczność realizacji społecznej gospodarki rynkowej? Jak wygląda sytuacja poziomu tych nierówności w Polsce?". Sformułowano również pytanie dodatkowe, jako przyczynek do

\footnotetext{
1 Ustawa z dnia 2 kwietnia 1997 r., Konstytucja Rzeczypospolitej Polskiej (Dz.U. 1997 Nr 78, poz. 483).

2 J. Famielec, Rola przedsiębiorczości w społecznej gospodarce rynkowej (wzorce Erharda i Euckena), [w:] Społeczna gospodarka rynkowa: Polska i integracja europejska, E. Mączyńska, P. Pysz (red.), PTE, Warszawa 2018, s. 73.

3 E. Mączyńska, Ordoliberalizm i społeczna gospodarka rynkowa jako podstawy inkluzywnego systemu społeczno-gospodarczego, [w:] Społeczna gospodarka rynkowa: Polska i integracja europejska, E. Mączyńska, P. Pysz (red.), PTE, Warszawa 2018, s. 172.

4 Najważniejsze publikacje w języku polskim w tym temacie to: G. Therborn, Nierówność, która zabija, PWN, Warszawa 2015; A.B. Atkinson, Nierówności. Co da się zrobić?, Wydawnictwo Krytyki Politycznej, Warszawa 2017; A. Deaton, Wielka ucieczka. Zdrowie, bogactwo i źródła nierówności, PWN, Warszawa 2016; J.E. Stiglitz, Cena nierówności, Wydawnictwo Krytyki Politycznej, Warszawa 2015; R. Wilkinson, K. Pickett, Duch równości, Wydawnictwo Czarna Owca, Warszawa 2011; T. Piketty, Kapitat w XXI wieku, Wydawnictwo Krytyki Politycznej, Warszawa 2015.
} 
dalszych, rozszerzonych badań na tematem: „Jakie są potencjalne czynniki zwiększające lub zmniejszające nierówności majątkowe?”.

\section{Nierówności ekonomiczne - podstawowe zagadnienia}

Sama nierówność, wychodząc od etymologii tego pojęcia, jest zaprzeczeniem (partykułą) słowa równość. Jak czytamy: „Aby oddać silny związek między nierównością i równością, możemy powiedzieć, że są to dwie strony tego samego medalu, żadna z nich bowiem nie istnieje bez drugiej" ${ }^{5}$.

W praktyce społecznej nie jest możliwy do osiągnięcia stan równości. Zawsze będzie więc mowa o większej lub mniejszej nierówności, jej wzroście lub spadku. Nawet jeżeli uznano by, że pożądane jest np. wprowadzenie równej wysokości emerytury dla wszystkich emerytów, oznaczałoby to jednocześnie stan nierówności tych ludzi pod względem np. stażu pracy. Mimo różnic w ilości przepracowanych lat otrzymywaliby oni takie same świadczenie emerytalne. Tak więc równość pod względem jednej cechy będzie jednocześnie oznaczać nierówność pod względem innej cechy.

Nierówności ekonomiczne są podzbiorem większego zbioru nierówności społecznych. Można je zdefiniować jako brak równości poszczególnych grup społecznych (również jednostek) pod względem różnych cech społecznych (nie psychofizycznych), w tym między innymi: płci, wykształcenia, dostępu do dóbr i usług kulturalnych, zdrowia, władzy, prestiżu itp. Jeżeli do analizy nierówności użyjemy cech ekonomicznych, takich jak dochód i majątek, uzyskujemy nierówności ekonomiczne. Tak więc nierówności ekonomiczne można zdefiniować jako nierówności społeczne pod względem cech ekonomicznych takich jak dochód i majątek.

Stwierdzenie nierówności wymaga dokonania porównania obiektów między sobą (opis, podejście pozytywne) lub porównania ich do określonego wzoru (ocena istniejącego stanu, podejście normatywne). Dodatkowo konieczne jest wskazanie cechy, pod kątem której dokonywane będzie porównanie (a w konsekwencji czego będzie dotyczyć nierówność).

\section{Badanie - źródło danych}

W badaniu wykorzystano wyniki Badania Zasobności Gospodarstw Domowych (BZGD lub HFCS). W organizowaniu badania uczestniczy Europejski Bank Centralny, banki centralne wszystkich państw strefy euro, banki centralne Polski i Węgier oraz kilkanaście publicznych instytucji statystycznych (w tym GUS). W badaniu zbierane są szczegółowe dane o sytuacji majątkowej GD ${ }^{6}$, ich strukturze

${ }_{5}$ Dobrobyt społeczny, nierówności $i$ sprawiedliwość dystrybutywna, S.M. Kot, A. Malanowski, A. Węgrzecki (red.), Wydawnictwo Akademii Ekonomicznej w Krakowie, Kraków 2004.

6 W dalszej części artykułu używany będzie skrót „GD” na oznaczenie gospodarstwa domowego. 
ekonomiczno- demograficznej oraz dochodach i wydatkach konsumpcyjnych. Badanie realizowane jest cyklicznie (co 2-3 lata) ${ }^{7}$.

W odniesieniu do Polski w niniejszym opracowaniu wykorzystano wyniki dwóch rund badania: styczeń/luty 2014 [ECB 2016a, NBP 2015a] i wrzesień/ listopad 2016 roku [NBP 2017a]. W Niemczech odbyły się trzy rundy badania: 2010/2011 [DB 2013], kwiecień/listopad 2014 [DB 2016] oraz marzec/październik 2017 [DB 2019].

Warto w tym miejscu zaznaczyć wyjątkowo niski wskaźnik odpowiedzi uzyskiwany w badaniach prowadzonych w Niemczech (18,7\%, 19\% i 25,9\%). Są to najniższe wyniki spośród wszystkich państw biorących udział w obu rundach badania. Średni wskaźnik odpowiedzi dla pierwszej rundy wyniósł $45,9 \%$, a dla drugiej $47,14 \%$. Wyniki uzyskane w niemieckich badaniach są więc ponad dwukrotnie niższe niż średnie dla wszystkich państw, w tym dla Polski (49,4\% i 48,7\%). Fakt ten może świadczyć o większym obciążeniu wyników niemieckich badań błędem niedoszacowania próby w zakresie najbardziej majętnych gospodarstw domowych, a w konsekwencji wskazywać na większe, faktyczne nierówności majątkowe i dochodowe niż wynikające z badania.

\section{Charakterystyka gospodarstw domowych Polski i Niemiec}

Jednostką statystyczną w badaniu HFCS jest gospodarstwo domowe. Jest to grupa ludzi zamieszkująca razem, wspólnie dzieląca dochody i ponosząca koszty. W przypadku indywidualnych cech, mierzonych w czasie badania, dotyczą one tzw. osoby referencyjnej ${ }^{8}$ (osoby odniesienia, głowy gospodarstwa domowego). W badaniu jest to osoba najlepiej zorientowana w sytuacji GD, z którą prowadzony był wywiad ankietowy.

Należy zaznaczyć, że w przypadku trzeciej rundy niemieckiego badania nie zostały opublikowane dane dotyczące charakterystyki GD. Podobnie raport z polskiego badania w 2016 roku nie zawiera danych tego typu. W związku z tym charakterystyka GD w obu krajach została dokonana z wykorzystaniem danych udostępnionych w nowszym raporcie ECB, tj. dla 2014 roku.

Wybrano następujące cechy demograficzne badanych gospodarstw: liczba członków GD, status mieszkaniowy, wiek OR, status na rynku pracy i wykształcenie. Tabela 1 prezentuje i zestawia te charakterystyki dla Polski i Niemiec w dwóch pierwszych rundach badania na tle średnich wartości w strefie euro.

Wielkość GD jest wyraźnie większa w przypadku Polski. Największą grupę stanowią dwuosobowe GD. W przypadku Niemiec przeważają gospodarstwa jednoosobowe. Średnia wielkość wynosi 2,7 osoby w Polsce i 2 osoby w Niemczech. Średnia dla strefy euro to 2,27 osoby.

\footnotetext{
7 Szersze omówienie tematu metodyki badań, sposobu ich przeprowadzenia, uzyskanych danych i ich jakości można odnaleźć w aneksach metodologicznych do poszczególnych badań.

8 W dalszej części artykułu używany będzie skrót „OR” dla oznaczenia osoby referencyjnej.
} 
W Polsce zdecydowanie przeważają GD będące właścicielem miejsca zamieszkania $(77,5 \%)$, przy czym $12,1 \% \mathrm{z}$ nich spłaca zaciągnięty na ich zakup kredyt mieszkaniowy. W Niemczech jedynie 44,3\% GD mieszka we własnym mieszkaniu lub domu (16,5\% spłaca kredyt mieszkaniowy). Wynik dla strefy euro to odpowiednio 61,2\% i 19,7\%. Poziom własności głównego miejsca zamieszkania w Niemczech jest więc niski w porównaniu ze średnią europejską i Polską (w badaniu wyższy wskaźnik zanotowano na Słowacji - 85,4\%, Węgrzech - 84,3\%, w Estonii - 83,1\% i na Malcie - 80,2\%).

Kolejne cechy dotyczą OR. Charakterystyka GD Polski i Niemiec jest dosyć podobna: średni wiek OR to odpowiednio 51,4 i 52,6 lat; OR to pracownik najemny, posiadający średnie wykształcenie. Można zwrócić uwagę na wyższy udział OR w wieku $65+$ w strefie euro $(29,8 \%)$ niż w Polsce $(16,3 \%)$ i Niemczech $(21,4 \%)$ oraz na znacznie wyższy udział osób z podstawowym wykształceniem w strefie euro (32\%) w porównaniu z Polską $(14,4 \%)$ i Niemcami (11\% - najniższy udział wśród wszystkich państw biorących udział w badaniu).

Tabela 1 .

Charakterystyka badanych GD pod względem cech demograficznych (\%)

\begin{tabular}{|c|c|c|c|c|c|c|}
\hline & & $\begin{array}{l}\text { Strefa euro } \\
\text { (2011) }\end{array}$ & $\begin{array}{l}\text { Strefa euro } \\
\text { (2014) }\end{array}$ & $\begin{array}{l}\text { Niemcy } \\
\text { (2011) }\end{array}$ & $\begin{array}{l}\text { Niemcy } \\
\text { (2014) }\end{array}$ & $\begin{array}{l}\text { Polska } \\
\text { (2014) }\end{array}$ \\
\hline \multirow{5}{*}{$\begin{array}{l}\text { Wielkość } \\
\text { GD }\end{array}$} & 1 & 32 & 32,9 & 39,6 & 40,3 & 24 \\
\hline & 2 & 32,2 & 31,7 & 34,5 & 34,6 & 25,7 \\
\hline & 3 & 16,3 & 16,1 & 12,8 & 12,5 & 20,2 \\
\hline & 4 & 14 & 13,9 & 9,4 & 9,1 & 16,2 \\
\hline & $5+$ & 5,6 & 5,4 & 3,8 & 3,4 & 13,9 \\
\hline \multirow{3}{*}{$\begin{array}{l}\text { Status } \\
\text { mieszkaniowy }\end{array}$} & Własność & 40,6 & 41,5 & 26,2 & 27,8 & 65,4 \\
\hline & $\begin{array}{l}\text { Własność z kre- } \\
\text { dytem }\end{array}$ & 19,2 & 19,7 & 18 & 16,5 & 12,1 \\
\hline & Najem/inne & 40,2 & 38,8 & 55,8 & 55,7 & 22,6 \\
\hline \multirow{6}{*}{$\begin{array}{l}\text { Wiek } \\
\text { OR }\end{array}$} & $16-34$ & 15,9 & 14,4 & 18 & 18,4 & 16,6 \\
\hline & $35-44$ & 19,5 & 17,8 & 18,1 & 15,5 & 19,5 \\
\hline & $45-54$ & 19,9 & 20 & 20,3 & 20,7 & 20,1 \\
\hline & $55-64$ & 17,1 & 18 & 14,9 & 16,8 & 21,8 \\
\hline & $65-74$ & 14,5 & 14,8 & 16,1 & 14,1 & 12,2 \\
\hline & $75+$ & 13,2 & 15 & 12,7 & 14,4 & 9,7 \\
\hline \multirow{4}{*}{$\begin{array}{l}\text { Status na } \\
\text { rynku pracy } \\
\text { OR }\end{array}$} & Pracownik & 48,3 & 48,2 & 51,3 & 56 & 51,3 \\
\hline & Samozatrudnienie & 9 & 8,7 & 7,4 & 8,2 & 11,2 \\
\hline & Emeryt & 31,9 & 30,9 & 30,5 & 28,3 & 26,4 \\
\hline & $\begin{array}{l}\text { Inny, nie pracu- } \\
\text { jący }\end{array}$ & 10,8 & 12,1 & 10,8 & 7,5 & 11,2 \\
\hline
\end{tabular}




\begin{tabular}{|c|c|c|c|c|c|c|}
\hline & & $\begin{array}{l}\text { Strefa euro } \\
\text { (2011) }\end{array}$ & $\begin{array}{c}\text { Strefa euro } \\
(2014)\end{array}$ & $\begin{array}{l}\text { Niemcy } \\
\text { (2011) }\end{array}$ & $\begin{array}{l}\text { Niemcy } \\
\text { (2014) }\end{array}$ & $\begin{array}{l}\text { Polska } \\
\text { (2014) }\end{array}$ \\
\hline \multirow{3}{*}{$\begin{array}{l}\text { Wykształcenie } \\
\text { OR }\end{array}$} & Podstawowe & 33,1 & 32 & 12,7 & 11 & 14,4 \\
\hline & Średnie & 42,1 & 41,6 & 56,1 & 57,9 & 61 \\
\hline & Wyższe & 24,8 & 26,4 & 31,2 & 31,1 & 24,6 \\
\hline
\end{tabular}

Źródło: opracowanie własne na podstawie: ECB (2016b), The Eurosystem Household Finance and Consumption Survey: Results from the second wave, Statistics Paper Series 18, Household Finance and Consumption Network, European Central Bank, 2016; ECB (2017), The Household Finance and Consumption Survey. Wave 2. Statistical Tables, ECB (2017).

Porównując polskie i niemieckie GD pod względem powyższych cech demograficznych należy stwierdzić, że są one podobne pod względem cech OR (wiek, status na rynku pracy oraz wykształcenie), ale różnią się znacznie pod względem wielkości oraz własności głównego miejsca zamieszkania.

\section{Poziom majątku}

HFCS posługuje się pojęciem majątku netto. Jego wartość jest uzyskiwana jako różnica między aktywami (majątek brutto) a zobowiązaniami (pasywami) badanego GD ${ }^{9}$.

Przeciętny majątek netto gospodarstwa domowego w Polsce w 2016 roku wynosił 96,8 tys. euro ${ }^{10}$. W 2014 roku wynosił 93,6 tys. euro. Jeżeli użyjemy mediany jako miary tendencji centralnej, zamiast średniej arytmetycznej uzyskujemy znacznie niższe wartości: 61,2 tys. euro w 2016 roku i 55,5 tys. euro w 2014 roku.

U naszego zachodniego sąsiada poziom majątku netto jest znacznie większy w wypadku średniej arytmetycznej. W 2017 roku było to 232,8 tys. euro. Wyniki z poprzednich rund to odpowiednio 209,2 tys. euro w 2010 roku oraz 214,3 tys. euro w 2014 roku. Mediany majątku netto są w każdym przypadku znacznie niższe niż średnia i wynoszą: 70,8 tys. euro w 2017 roku, 60,8 tys. euro w 2014 roku oraz 55,1 tys. euro w 2010 roku.

Stosunek między poziomem majątku netto mierzonym średnią w Niemczech i Polsce wynosi 2,4 . W przypadku mediany spada ona do 1,16 . Dodatkowo aż $8,7 \%$ niemieckich gospodarstw domowych posiadało w 2014 roku ujemny majątek netto. Wskaźnik ten dla Polski wyniósł 2,7\%. Do 2017 roku sytuacja poprawiła się

\footnotetext{
9 W skład aktywów wchodzą aktywa rzeczowe (np. nieruchomości, samochody, kosztowności, majątek z prowadzonej działalności gospodarczej) i finansowe (depozyty, akcje, obligacje, należności, dobrowolne programy emerytalne i ubezpieczenia na życie). Zobowiązania to różnego rodzaju kredyty.

${ }^{10}$ Wartości w złotówkach zostały przeliczone na euro według średniego kursu NBP za lata 2016 i 2017 (odpowiednio (4,3625+4,257,6)/2=4,31005 PLN/EUR). Por. Zasobność gospodarstw domowych $w$ Polsce. Raport z pilotażowego badania 2016 r., NBP, Warszawa 2017.
} 
w Niemczech: wskaźnik spadł do poziomu 7,5\%. Podobnie w Polsce. W 2016 roku około $2,2 \%$ gospodarstw posiadało ujemny majątek.

Znacznie niższa wartość mediany w stosunku do średniej oznacza silną, prawostronną asymetrię rozkładu majątku w Polsce i w Niemczech, czyli nierówność w rozkładzie majątku. Jest ona charakterystyczna dla rozkładów majątku i dochodu we wszystkich nowoczesnych państwach [Allianz 2018, Credit Suisse 2018, OECD 2015, World Inequality Lab 2018]. Mniejsza relacja między poziomem mediany i średniej arytmetycznej w Polsce niż w Niemczech wskazuje na mniejszą nierówność majątku w przypadku naszego kraju.

\section{Struktura majątku}

Strukturę majątku netto GD w badanych krajach prezentuje tabela 2. Głównym składnikiem są aktywa rzeczowe. Ich udział w Polsce jest wyższy niż w strefie euro oraz w Niemczech. W związku z tym aktywa finansowe w Polsce odgrywają znacznie mniejszą rolę. Między 2014 a 2016 rokiem nastąpiło znaczne zwiększenie się udziału aktywów finansowych w Polsce, choć nadal do poziomu prawie dwukrotnie niższego niż średnia europejska. W przypadku Niemiec tendencja była odwrotna. Udział aktywów finansowych między 2014 a 2017 rokiem uległ zmniejszeniu.

Tabela 2 .

Struktura majątku GD

\begin{tabular}{l|c|c|c|c|c}
\hline Składniki majątku & $\begin{array}{c}\text { Strefa euro } \\
(\mathbf{2 0 1 4 )}\end{array}$ & $\begin{array}{c}\text { Polska } \\
(\mathbf{2 0 1 4 )}\end{array}$ & $\begin{array}{c}\text { Polska } \\
(\mathbf{2 0 1 6 )}\end{array}$ & $\begin{array}{c}\text { Niemcy } \\
\mathbf{( 2 0 1 4 )}\end{array}$ & $\begin{array}{c}\text { Niemcy } \\
\text { (2017) }\end{array}$ \\
\hline Aktywa rzeczowe & $82,20 \%$ & $95,40 \%$ & $91,60 \%$ & $77,60 \%$ & $81,43 \%$ \\
\hline Aktywa finansowe & $17,80 \%$ & $4,60 \%$ & $8,40 \%$ & $22,40 \%$ & $18,57 \%$ \\
\hline Składniki majątku rzeczowego & $\begin{array}{c}\text { Strefa euro } \\
(\mathbf{2 0 1 4 )}\end{array}$ & $\begin{array}{c}\text { Polska } \\
(\mathbf{2 0 1 4 )}\end{array}$ & $\begin{array}{c}\text { Polska } \\
(\mathbf{2 0 1 6 )}\end{array}$ & $\begin{array}{c}\text { Niemcy } \\
(\mathbf{2 0 1 4 )}\end{array}$ & $\begin{array}{c}\text { Niemcy } \\
(\mathbf{2 0 1 7})\end{array}$ \\
\hline Miejsce zamieszkania & $60,20 \%$ & $69,90 \%$ & $70,70 \%$ & $52 \%$ & $55,10 \%$ \\
\hline Inna nieruchomość & $22,30 \%$ & $10,50 \%$ & $12,30 \%$ & $26,10 \%$ & $24,40 \%$ \\
\hline Majątek firmowy & $11,70 \%$ & $16,10 \%$ & $12,80 \%$ & $16,50 \%$ & $15,20 \%$ \\
\hline Samochód & $3,50 \%$ & $3,20 \%$ & $3,80 \%$ & $4,10 \%$ & $3,80 \%$ \\
\hline Kosztowności & $2,30 \%$ & $0,30 \%$ & $0,40 \%$ & $1,30 \%$ & $1,50 \%$ \\
\hline
\end{tabular}

Źródło: opracowanie własne na podstawie źródeł jak w tabeli 1 oraz NBP (2017a) Zasobność gospodarstw domowych $w$ Polsce. Raport z pilotażowego badania 2016 r., NBP, Warszawa 2017; DB (2019) Household wealth and finances in Germany: results of the 2017 survey, Monthly Report, Deutsche Bundesbank, June 2019.

Skład aktywów rzeczowych w Polsce i Niemczech jest podobny, choć występują charakterystyczne różnice. Największa dotyczy udziału głównego miejsca zamieszkania. Udział tej nieruchomości w majątku w Polsce jest wyższy niż średnio 
w strefie euro oraz w Niemczech. Druga ze składowych, tj. nieruchomość nie będąca głównym miejscem zamieszkania stanowi z kolei większy udział w majątku w Niemczech niż w Polsce. Może to być spowodowane faktem, że gospodarstwa niemieckie w dużo większym stopniu korzystają z wynajmu (z powodu znacznie mniejszego udziału własności miejsca zamieszkania). W takiej sytuacji, gospodarstwa zamożniejsze posiadają inne nieruchomości, które wynajmują. Porównując udział obu rodzajów nieruchomości razem w majątku rzeczowym otrzymujemy w 2016 roku Polsce 83\%, w strefie euro w 2014 roku 82,5\%, a w Niemczech w 2017 roku 79,5\%. Widać wówczas, że różnice nie są już duże.

Majątek związany z działalnością gospodarczą jest trzecim w kolejności składnikiem majątku rzeczowego. W przypadku Niemiec jest on wyraźnie większy niż w Polsce, ale również większy niż średnia w strefie euro. Można zauważyć również spadek udziału tego składnika majątku w Polsce na korzyść innej niż główna nieruchomość. Udział wartości samochodów oraz kosztowności w majątku jest znacznie niższy i stabilny w czasie zarówno w Polsce, jak i w Niemczech. Ciekawym zjawiskiem jest wysoki średni udział kosztowności w strefie euro, który wynosi $2,3 \%$. Jest on spowodowany bardzo dużym udziałem tego składnika w majątku we Francji, gdzie wynosi aż 5,9\%.

Dodatkowo warto w tym miejscu przeanalizować zadłużenie GD w zakresie kredytów mieszkaniowych. Taki kredyt, o średniej wartości 125 tys. euro, spłacało w 2017 roku $21 \%$ niemieckich GD. W Polsce wskaźnik ten wyniósł w 2016 roku 13,9\%, a średnia wartość kredytu wyniosła 36,3 tys. euro.

\section{Nierówności majątku}

Analizę należy rozpocząć od syntetycznych mierników nierówności rozkładu majątku. Przedstawiono je w tabeli 3. W obu analizowanych krajach występuje koncentracja dużej części majątku w podgrupie najbardziej majętnych GD. Nierówności majątkowe w Niemczech są wyższe niż średnia obserwowana w strefie euro. Różnica w stosunku do Polski jest jeszcze większa. Wskazują na to wszystkie przedstawione wskaźniki. Najczęściej stosowany współczynnik Giniego ${ }^{11}$ przyjmuje w Niemczech wartość 74\% w 2017 roku, w porównaniu z 56,8\% w Polsce w roku 2016 i 68,5\% jako średniej wartości w strefie euro w 2014 roku. Medianowe GD w Niemczech (próg P50) posiada prawie 8 razy mniejszy majątek niż minimalny majątek $10 \%$ najbogatszych GD. Relacja ta dla Polski jest ponad dwukrotnie niższa. Poniżej średniej wartości majątku znajduje się około 75\% niemieckich GD. W Polsce wartość majątku niższą niż średnia krajowa posiada około $65 \%$ GD. Porównując majątki polskich i niemieckich GD w wartościach bezwzględnych okazuje się,

\footnotetext{
${ }^{11}$ Jest to miara koncentracji (nierównomierności) rozkładu. Przyjmuje on wartość od 0 (dla całkowicie równego rozkładu, wszystkie GD mają majątek dokładnie taki sam) do 1 (dla całkowicie nierównego rozkładu, jedno GD posiada cały majątek, a wszystkie pozostałe nie mają nic). Wzrost współczynnika oznacza wzrost nierówności. Często podaje się go w \%, przyjmuje wówczas wartości od 0 do 100 .
} 
że prawie 50\% najbiedniejszych polskich GD ma majątek wyższy niż 50\% najbiedniejszych niemieckich GD.

Tabela 3 .

Nierówności majątkowe - mierniki syntetyczne

\begin{tabular}{l|c|c|c|c|c|c|c}
\hline & $\begin{array}{c}\text { Strefa } \\
\text { euro } \\
(\mathbf{2 0 1 0 )}\end{array}$ & $\begin{array}{c}\text { Niemcy } \\
(\mathbf{2 0 1 0 )}\end{array}$ & $\begin{array}{c}\text { Strefa } \\
\text { euro } \\
(\mathbf{2 0 1 4 )}\end{array}$ & $\begin{array}{c}\text { Niemcy } \\
(\mathbf{2 0 1 4 )}\end{array}$ & $\begin{array}{c}\text { Polska } \\
(\mathbf{2 0 1 4})\end{array}$ & $\begin{array}{c}\text { Niemcy } \\
(\mathbf{2 0 1 7})\end{array}$ & $\begin{array}{c}\text { Polska } \\
(\mathbf{2 0 1 6})\end{array}$ \\
\hline Średnia [tys. euro] & 230,1 & 195,2 & 223,3 & 214,5 & 93,60 & 232,8 & 96,82 \\
\hline Mediana [tys. euro] & 116,3 & 51,4 & 104,1 & 60,4 & 55,47 & 70,8 & 61,16 \\
\hline Średnia/Mediana & 2,0 & 3,8 & 2,1 & 3,6 & 1,7 & 3,3 & 1,6 \\
\hline P90/P10 & 427,6 & 442,3 & 503,5 & 468,0 & 351,3 & 555,4 & 107,3 \\
\hline P90/P50 & 4,7 & 8,6 & 4,8 & 7,7 & 3,7 & 7,8 & 3,2 \\
\hline P80/P20 & 40,1 & 75 & 41 & 114 & 13 & 111 & 8 \\
\hline Współ. Giniego & 68 & 75,8 & 68,5 & 76,2 & 57,9 & 74 & 56,8 \\
\hline
\end{tabular}

Źródło: opracowanie własne na podstawie źródeł jak w tabeli 2.

Wykres 1 .

Porównanie wartości majątku netto dla decyli GD w dwóch kolejnych rundach badania

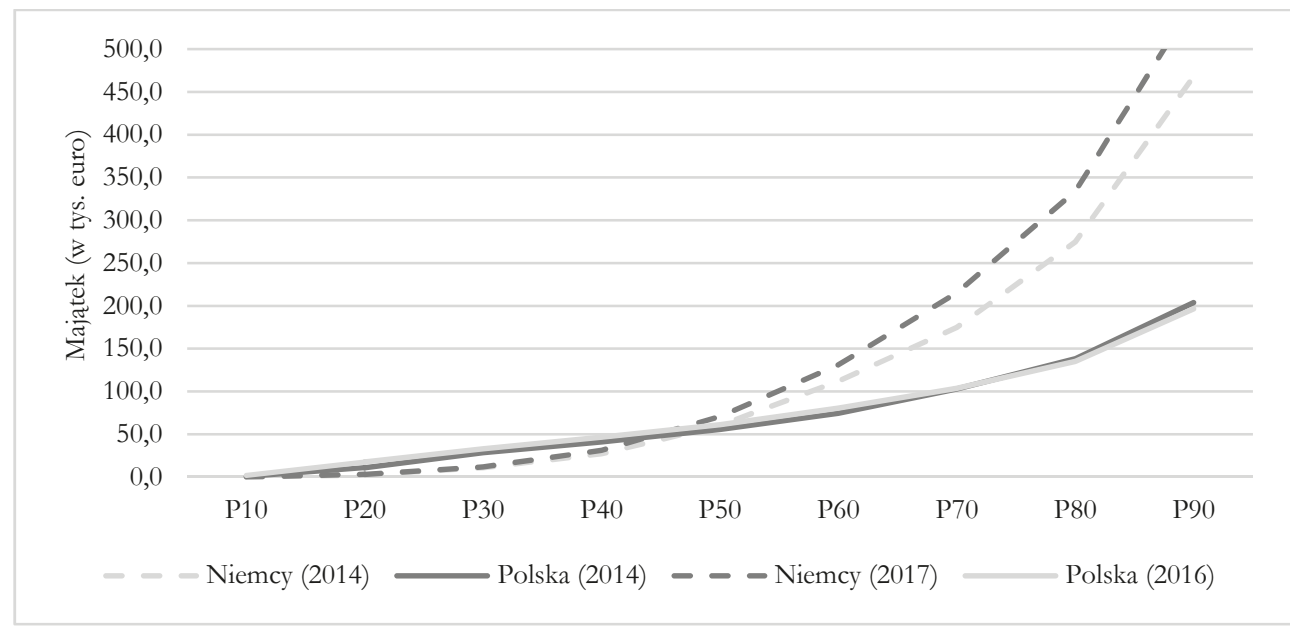

Źródło: opracowanie własne na podstawie źródeł jak w tabeli 3.

Analiza zmian w czasie przedstawiona jest na wykresie 1. Widać, że nierówności majątkowe w Niemczech wzrosły, szczególnie po prawej stronie rozkładu (mimo spadku współczynnika Giniego). Linia obrazująca poziom majątku dla poszczególnych decyli rozkładu z 2016 roku jest po prawej stronie wyraźnie powyżej poziomu z 2014 roku. W przypadku Polski mamy sytuację odwrotną. Dla około $60-65 \%$ polskich GD poziom majątku w 2016 roku był wyższy niż w 2014 roku. 
Zaprezentowane powyżej wskaźniki syntetyczne nie oddają tak wyraźnie zmian, jakie zaszły w rozkładzie majątku między drugą a trzecią rundą badania ${ }^{12}$.

\section{Czynniki zróżnicowania majątku}

Dane zbierane w czasie badania HFCS umożliwiają analizę poziomu majątku w podziale na różne cechy. W niniejszym artykule wybrano: dochód, wielkość GD, poziom wykształcenia OR, wiek OR, status OR na rynku pracy oraz dwa dodatkowe czynniki regionalne. Wszystkie one istotnie różnicują poziom posiadanego majątku. W przypadku niektórych cech dane zostały zagregowane, aby zachować porównywalność między wynikami dla Polski i Niemiec. Różnice zaznaczono na wykresie i w opisie. Jako wskaźnik opisujący średnie wartości majątku użyto mediany. Użytą miarą zróżnicowania jest relacja średniej do mediany. Porównując tę relację wewnątrz grup oraz pomiędzy grupami oceniono stopień wpływu zróżnicowania wewnątrzgrupowego oraz międzygrupowego na ogólne zróżnicowanie.

Pierwszym z analizowanych czynników jest dochód. Wraz z jego wzrostem rośnie wielkość majątku netto we wszystkich analizowanych przypadkach: strefy euro, Polski i Niemiec (Wykres 2).

Wykres 2 .

Zależność wysokości majątku od dochodu GD

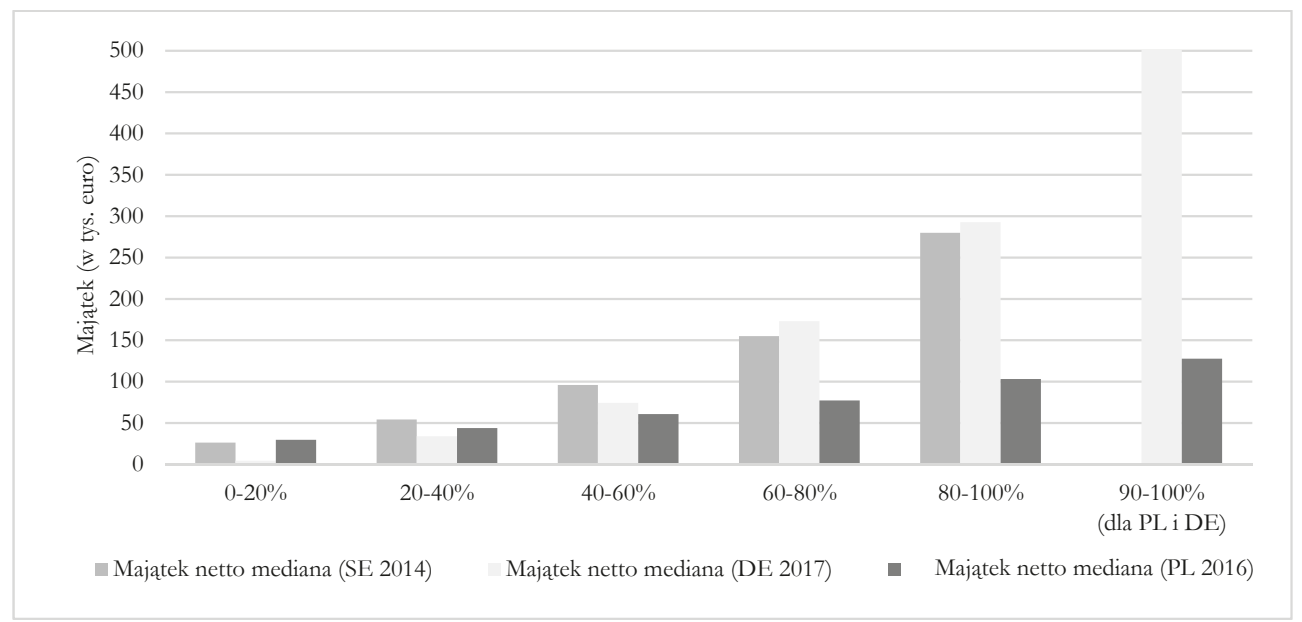

Źródło: jak w wykresie 1.

Najszybszy wzrost odnotowujemy w Niemczech i jest on największy w grupie $20 \%$ najbogatszych GD. Różnica między majątkiem pierwszego i dziesiątego

\footnotetext{
${ }^{12}$ Jest to podstawowa wada wskaźników syntetycznych. W jednej wartości opisują one stan nierówności. W przypadku jednoczesnych, ale przeciwstawnych co do kierunku zmian po prawej i lewej stronie same wartości wskaźników mogą się nie zmieniać lub zmieniać się na tyle mało, że sugeruje brak zmiany.
} 
decyla dochodu to prawie 120 razy. Dane dla strefy euro zagregowane są w pięć kategorii (w przypadku Polski i Niemiec dodatkowo wyodrębniono szóstą grupę zawierającą 10\% najbardziej majętnych GD). Majątek tej grupy dochodowej jest około $100 \%$ większy niż dolnego kwintyla. Najwolniejszy wzrost majątku wraz $\mathrm{z}$ dochodem obserwujemy w Polsce. Wzrost ten jest w miarę równomierny między poszczególnymi grupami GD. Majątek 10\% najwięcej zarabiających GD jest u nas 4,3 raza wyższy niż $20 \%$ najmniej zarabiających.

Kolejnym czynnikiem jest wielkość gospodarstw domowych. W Polsce majątek rośnie wraz z każdym wzrostem liczebności GD. W przypadku Niemiec widać, że wzrost majątku nie zależy od samego wzrostu liczebności, ale od tego, czy GD posiada dzieci. Majątek jest wyższy, gdy w GD nie ma dzieci. Najmniejszy majątek posiadają samotni rodzice z dziećmi, w dalszej kolejności jednoosobowe GD i rodziny rozszerzone (z liczbą dzieci większą niż dwoje). Największym majątkiem dysponują pary bez dzieci oraz pary z dwojgiem dzieci. W przypadku strefy euro, gdzie brak jest danych o strukturze GD (podział na dorosłych i dzieci) widać, że majątek bardzo szybko rośnie przy przejściu z jedno- do dwuosobowego GD (+180\%). Następnie stabilizuje się, ale jest zmienna (+/- 10-20\%). Rośnie dla dwu- i czteroosobowego GD, ale spada nieco dla trzy-, pięcio- i więcej osobowych GD.

Poziom wykształcenia wyraźnie różnicuje poziom majątku. We wszystkich analizowanych przypadkach największy poziom majątku posiadają GD dla OR z wyższym wykształceniem. W przypadku strefy euro majątek dla wykształcenia średniego i podstawowego jest na porównywalnym poziomie. W przypadku Niemiec brak wykształcenia oznacza brak majątku (kategorii „brak” nie ma w zestawieniach danych dotyczących Polski i strefy euro). W Polsce najniższy majątek dotyczy wykształcenia podstawowego. Majątek rośnie mniej więcej o $50 \%$ wraz ze zwiększaniem się poziomu wykształcenia z podstawowego na średnie i ze średniego na wyższe.

Wykres 3 .

Zależność wysokości majątku od wielkości GD

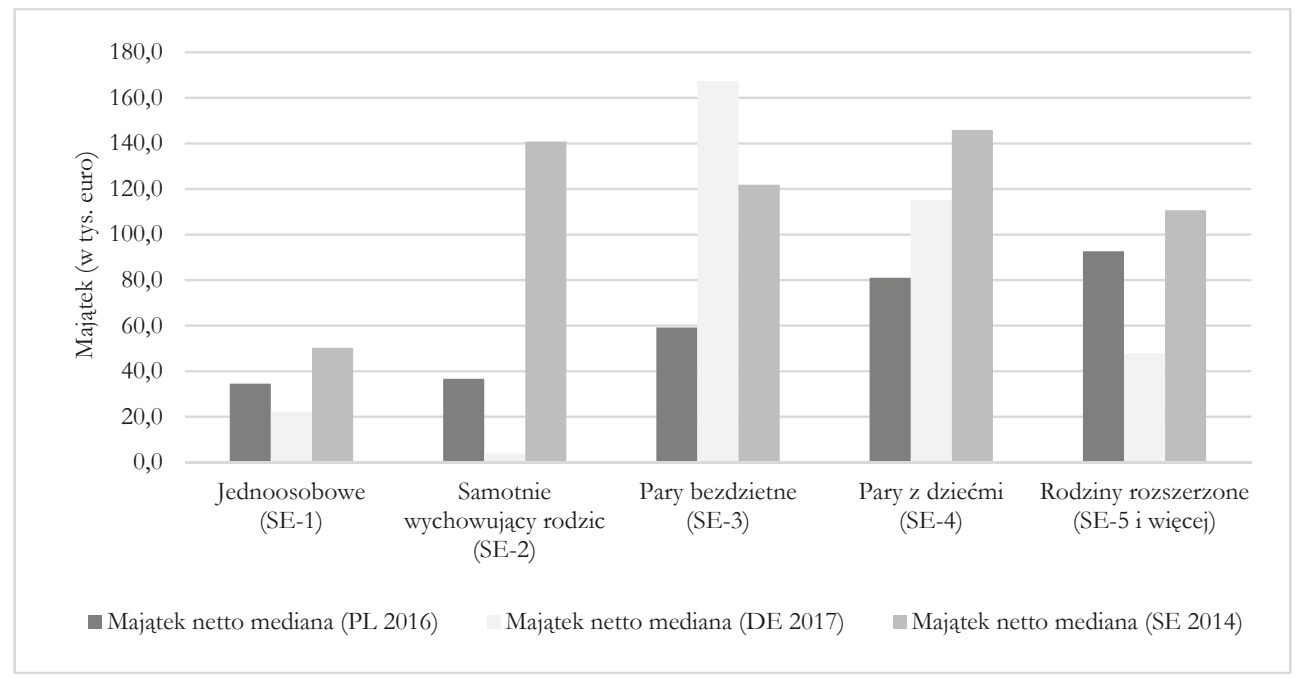

Źródło: jak w wykresie 1. 
Wykres 4.

Wysokości majątku w zależności od wykształcenia OR

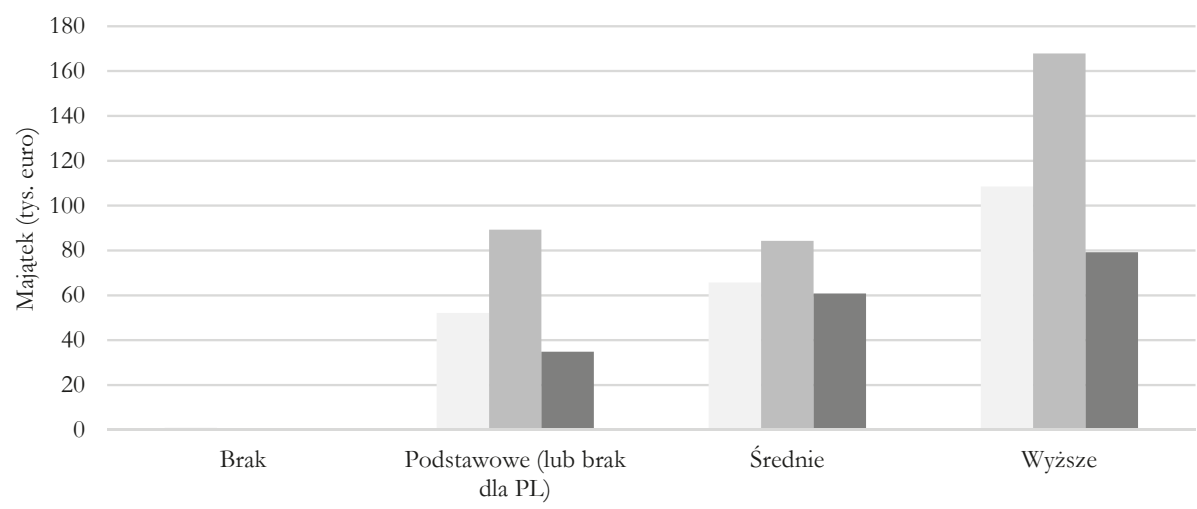

Majątek netto mediana (DE 2017) $\quad$ Majątek netto mediana (SE 2014) $\quad$ Majątek netto mediana (PL 2016)

Źródło: jak w wykresie 1.

Wykres 5.

Zależność wysokości majątku od wieku OR

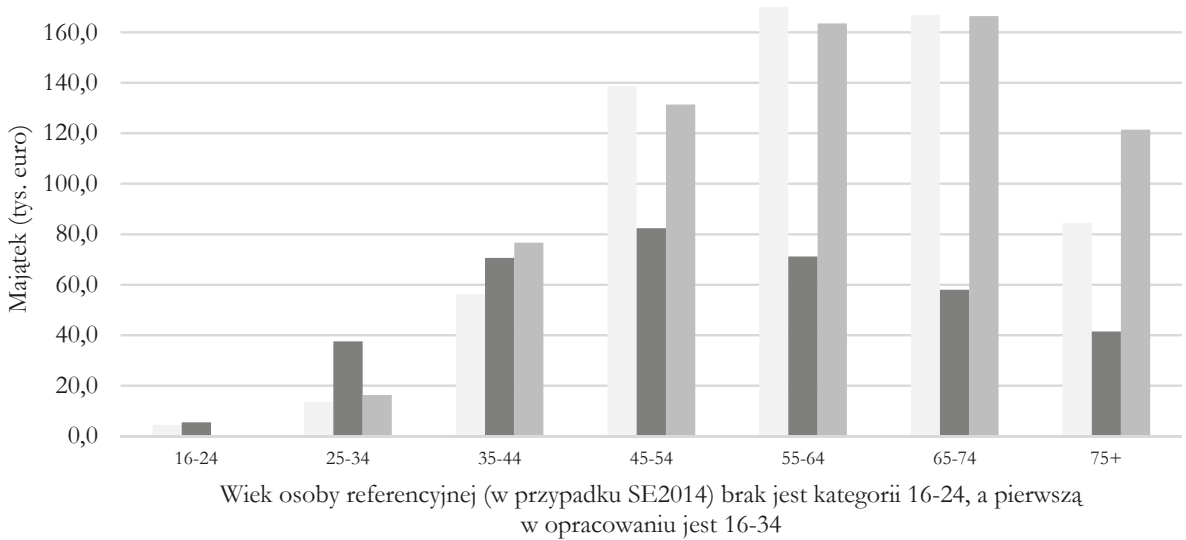

Majątek netto mediana (DE 2017) — Majątek netto mediana (PL 2016)

Majątek netto mediana (SE 2014)

Źródło: jak w wykresie 1.

Wiek OR prezentuje chyba najbardziej wyraźny wzór wpływu na majątek GD, zarówno w strefie euro - w Niemczech, jak i Polsce. Majątek rośnie do pewnego poziomu wraz z wiekiem OR, a następnie spada. W przypadku strefy euro maksymalny poziom majątku występuje w przedziale 55-64 lata. W przypadku Niemiec i Polski maksymalny majątek GD osiągają w przedziale 45-54 lata. Szybkość wzrostu majątku jest bardzo duża w przedziale 16-34 lata, następnie spada. 
Charakterystyczne jest, że w przypadku Niemiec najmniej majętną grupą są GD z przedziału 16-34, a najbardziej majętną 55-64 lata. W Polsce najmniej zamożna grupa to również 16-34, ale kolejna to już 75+. Największy majątek w Polsce osiągają GD w przedziale o 10 lat mniejszym niż niemieckie, czyli 44-55 lat. Sytuacja w strefie euro jest w tym zakresie bardziej podobna do niemieckiej. GD z wyższych przedziałów charakteryzują się stosunkowo wysokimi majątkami.

Kolejny analizowany czynnik to status OR na rynku pracy. Charakterystyczna sytuacja (i odmienna niż w Polsce i strefie euro jako całości) występuje w Niemczech. Największy majątek zgromadziły GD z OR opisaną jako emerytowany urzędnik. W przypadku pozostałych dwóch opracowań występuje tylko jedna kategoria - „emerytowany”. Mediana majątku niemieckiego emerytowanego urzędnika jest cztery razy wyższa niż pozostałych emerytów. Kolejne są GD z samozatrudnioną OR. Dalszy w kolejności jest majątek aktywnych urzędników i pracowników. Na samym końcu są GD z niezatrudnioną osobą referencyjną, które nie posiadają praktycznie żadnego majątku.

W Polsce i w strefie euro jako całości najmniejszy majątek występuje w kategorii GD z OR opisaną jako „inny niepracujący”, a największy w kategorii „,samozatrudniony”. Jednak w Polsce majątek „pracujących” i „emerytowanych” jest praktycznie taki sam. W przypadku strefy euro odmiennie: majątek „emerytowanych” jest dwa razy większy niż „pracujących”.

Poszczególne badania różnią się między sobą pod względem niektórych badanych cech GD. W przypadku Niemiec uwzględniono takie cechy jak: narodowość OR (niemiecka/inna) oraz region (wschód/zachód). W Polsce jest to klasa miejscowości zamieszkania (wieś/miasto). Wykres 7 prezentuje wysokość majątku GD w tych kategoriach.

W przypadku niemieckich GD widać bardzo wyraźnie zależność majątku od narodowości i regionu. Niskie poziomy obserwujemy w przypadku GD narodowości innej niż niemiecka oraz ze wschodnich landów Niemiec. Dla innych narodowości różnica wynosi 7,9 razy, a dla regionu 4,6.

W porównaniu z tym polskie różnice w majątku i dochodzie ze względu na klasę miejscowości zamieszkania są małe. Dla majątku wynosi około 1,5 raza na korzyść GD zakwalifikowanych jako mieszkających na wsi. Jest to w dużym stopniu spowodowane faktem zamieszkania znacznej liczby majętnych GD na obrzeżach dużych miast oraz większą powierzchnią nieruchomości położonych poza miastami, co wpływa na ich wartość (w przypadku miast są to najczęściej mieszkania).

Brak dostępu do szczegółowych danych nie pozwala matematycznie oddzielić wpływu nierówności wewnątrzgrupowych (np. między gospodarstwami z tym samym wykształceniem) i międzygrupowych (np. między gospodarstwami z różnych grup wykształcenia OR) ${ }^{13}$. Wykorzystując jednak dostępne w opracowaniach

\footnotetext{
${ }^{13}$ Jako przykład takiej analizy mogą posłużyć: K. Grejcz, Z. Żółkiewski, Majątek gospodarstw domowych w Polsce - wstępne wyniki, Prezentacja z Konferencji Naukowej Dtugoterminowe oszczędzanie, SGH, Warszawa 2016 oraz K. Grejcz, Z. Żółkiewski, Household wealth in Poland: the results of a new survey of household finance, „Bank i Kredyt” 2017, nr 48(3), s. 295-326.
} 
średnie arytmetyczne oraz mediany dla poszczególnych grup można sformułować pewne wnioski. Tabela 4 zawiera relacje średniej arytmetycznej do mediany dla wszystkich grup w analizowanych czynnikach różnicujących poziom majątku. Pogrubioną czcionką zaznaczono te wszystkie przypadki, gdy relacja (zróżnicowanie) w danej grupie przewyższa zróżnicowanie obliczone w ten sam sposób dla całej zbiorowości GD.

Wykres 6 .

Zależność wysokości majątku od statusu OR na rynku pracy

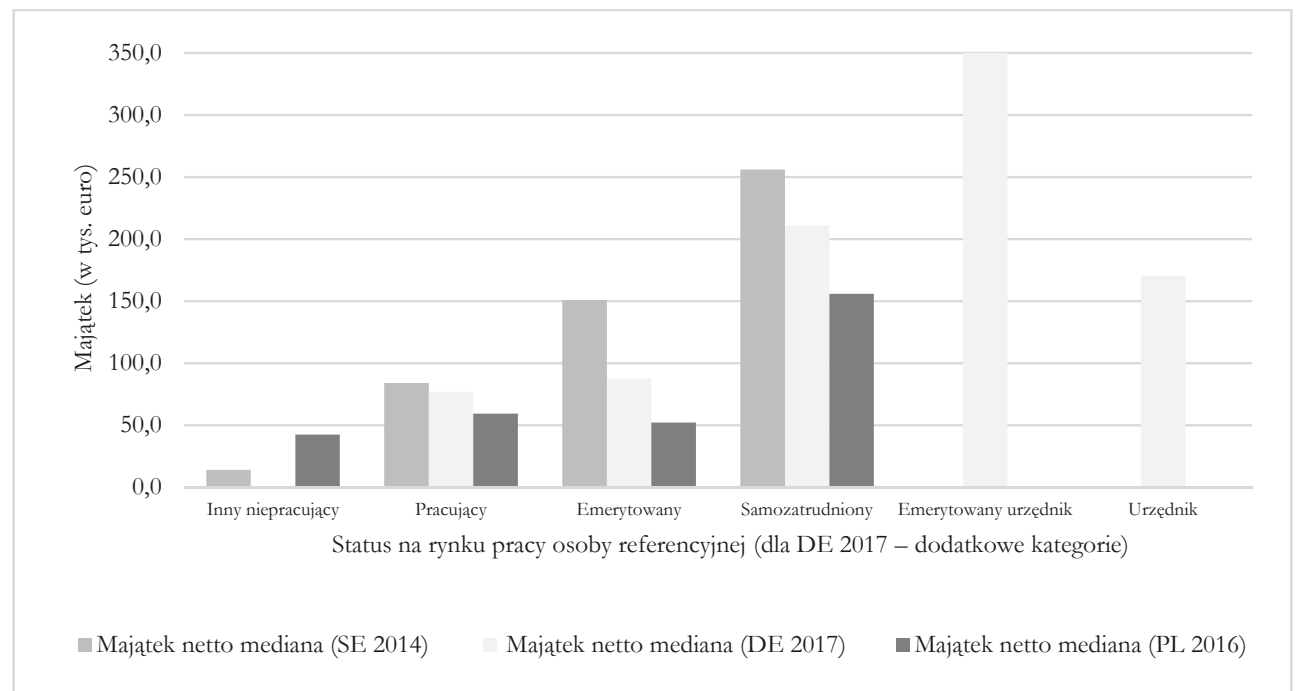

Źródło: jak w wykresie 1.

Wykres 7.

Zależność wysokości majątku od wybranych cech

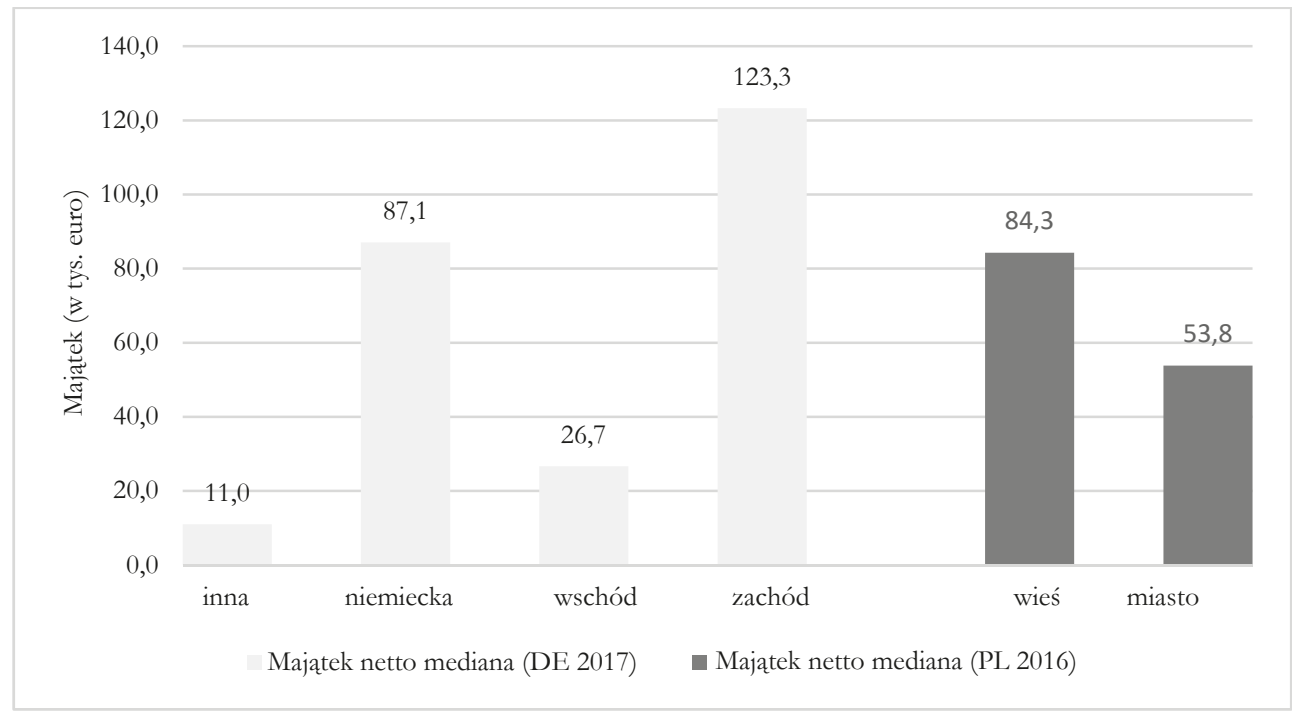

Źródło: jak w wykresie 1. 
Dla polskich GD w większości przypadków wyniki są poniżej wyniku dla całego zbioru. W tych wypadkach (5 na 27), gdy ta relacja jest większa, nie przekracza średniej o więcej niż $10 \%$ (największe zróżnicowanie ma miejsce dla wykształcenia jako czynnika różnicującego). Na niskie zróżnicowanie rozkładu majątku w Polsce składają się więc zarówno małe nierówności wewnątrzgrupowe, jak i międzygrupowe.

Tabela 4 .

Nierówności majątkowe dla poszczególnych czynników

\begin{tabular}{|c|c|c|c|c|}
\hline \multicolumn{2}{|c|}{ Relacja średnia/mediana } & $\begin{array}{l}\text { Strefa euro } \\
(2014)\end{array}$ & $\begin{array}{l}\text { Niemcy } \\
(2017)\end{array}$ & $\begin{array}{l}\text { Polska } \\
\text { (2016) }\end{array}$ \\
\hline \multicolumn{2}{|l|}{ Wszystkie GD } & 2,15 & 3,29 & 1,58 \\
\hline \multirow{6}{*}{ Dochód } & $0-20 \%$ & 3,18 & 12,14 & 1,45 \\
\hline & $20-40 \%$ & 2,15 & 4,13 & 1,43 \\
\hline & $40-60 \%$ & 1,74 & 2,18 & 1,37 \\
\hline & $60-80 \%$ & 1,53 & 1,35 & 1,34 \\
\hline & $80-100 \%$ & 1,83 & 1,20 & 1,40 \\
\hline & 90-100\% (dla PL i DE) & - & 1,52 & 1,85 \\
\hline \multirow{5}{*}{ Wielkość GD } & Jednoosobowe (SE-1) & 2,83 & 6,39 & 1,25 \\
\hline & $\begin{array}{l}\text { Samotnie wychowujący rodzic } \\
\text { (SE-2) }\end{array}$ & 1,89 & 14,87 & 1,24 \\
\hline & Pary bezdzietne (SE-3) & 1,92 & 1,98 & 1,20 \\
\hline & Pary z dziećmi (SE-4) & 1,93 & 2,56 & 1,20 \\
\hline & Rodziny rozszerzone (SE-5 i więcej) & 2,54 & 4,07 & 1,06 \\
\hline \multirow{7}{*}{ Wiek OR } & $16-24$ & - & 2,89 & 1,28 \\
\hline & 25-34 (dla SE 16-34) & 4,20 & 4,74 & 1,11 \\
\hline & $35-44$ & 2,17 & 2,88 & 1,19 \\
\hline & $45-54$ & 1,99 & 2,45 & 1,12 \\
\hline & $55-64$ & 1,95 & 1,75 & 1,23 \\
\hline & $65-74$ & 1,72 & 1,88 & 1,25 \\
\hline & $75+$ & 1,79 & 2,65 & 1,26 \\
\hline \multirow{6}{*}{$\begin{array}{l}\text { Status na ryn- } \\
\text { ku pracy OR }\end{array}$} & Inny niepracujący & 6,77 & 58,33 & 1,23 \\
\hline & Pracujący & 2,10 & 2,81 & 1,13 \\
\hline & Emerytowany & 1,65 & 2,55 & 1,24 \\
\hline & Samozatrudniony & 2,24 & 3,38 & 1,31 \\
\hline & Emerytowany urzędnik & - & 1,14 & - \\
\hline & Urzędnik & - & 1,73 & - \\
\hline \multirow{4}{*}{$\begin{array}{l}\text { Wykształcenie } \\
\text { OR }\end{array}$} & Brak & - & 24,27 & - \\
\hline & Podstawowe & 1,76 & 3,74 & 1,66 \\
\hline & Średnie & 2,20 & 3,23 & 1,51 \\
\hline & Wyższe & 2,16 & 2,78 & 1,65 \\
\hline
\end{tabular}




\begin{tabular}{|c|c|c|c|c|}
\hline \multicolumn{2}{|c|}{ Relacja średnia/mediana } & $\begin{array}{c}\text { Strefa euro } \\
(2014)\end{array}$ & $\begin{array}{c}\text { Niemcy } \\
(2017)\end{array}$ & $\begin{array}{l}\text { Polska } \\
\text { (2016) }\end{array}$ \\
\hline \multirow{6}{*}{ Inne czynniki } & wschód (DE) & - & 3,49 & - \\
\hline & zachód (DE) & - & 2,19 & - \\
\hline & narodowość niemiecka (DE) & - & 2,91 & - \\
\hline & narodowość inna (DE) & - & 9,86 & - \\
\hline & wieś (PL) & - & - & 1,46 \\
\hline & miasto $(\mathrm{PL})$ & - & - & 1,56 \\
\hline
\end{tabular}

Źródło: jak w wykresie 1.

Zróżnicowanie wśród niemieckich GD jest największe. Dane w tabeli 4 wskazują, że w dużej liczbie przypadków zróżnicowanie wewnątrzgrupowe jest wyższe niż dla całej zbiorowości GD (13 na 32). Dodatkowo różnice te w porównaniu do występujących w Polsce i strefie euro są znacznie wyższe, nawet kilkunastokrotnie. Grupy te to najmniej zarabiający, bez wykształcenia i nie pracujący. Oznacza to, że w tych grupach są GD z bardzo wysokim majątkiem w stosunku do większości innych wewnątrz grup. Prawdopodobnym czynnikiem może być tutaj dziedziczenie lub darowizny. W przypadku samotnie wychowujących rodziców może to być efekt występowania GD z wysokim majątkiem, ale podzielonych w wyniku rozwodu. W przypadku zróżnicowania w grupie GD narodowości innej niż niemiecka może to być występowanie w grupie mniejszej liczby GD z OR z wysokimi kwalifikacjami (np. lekarze). Na podstawie przytoczonych danych wydaje się być uzasadnionym stwierdzenie, że wysokie nierówności majątkowe w Niemczech wynikają z jednocześnie występującego wysokiego zróżnicowania wewnątrz-, jak i międzygrupowego.

\section{Podsumowanie}

Badanie zostało przeprowadzone z wykorzystaniem danych zagregowanych (brak dostępu do danych z poszczególnych kwestionariuszy). Pozwala jednak wyciągnąć kilka interesujących wniosków:

- Średni poziom majątku w przypadku niemieckich GD jest 2,4 razy większy niż polskich. W przypadku mediany różnica spada do 1,15 razy. Wskazuje to na dużo mniejszą nierówność rozkładu majątku w Polsce w porównaniu z Niemcami. Potwierdzają to pozostałe wykorzystane syntetyczne wskaźniki zróżnicowania.

- Struktura majątku jest podobna. Przeważają w niej aktywa rzeczowe. Szczególnie widoczne jest dużo większe rozpowszechnienie w Polsce posiadania głównego miejsca zamieszkania w porównaniu z Niemcami.

- W przypadku obu krajów dochód i wielkość GD oraz wykształcenie, wiek, status na rynku pracy OR wpływają na stopień nierówności. W Niemczech 
są one dodatkowo i silnie zwiększane przez takie cechy jak narodowość OR oraz region (wschód/zachód).

- Na niskie nierówności majątkowe w Polsce mają wpływ zarówno niskie zróżnicowanie wewnątrz-, jak i międzygrupowe. W przypadku Niemiec sytuacja jest odwrotna: jednoczesne wysokie zróżnicowanie wewnątrz, jak i międzygrupowe tworzy wysokie ogólne nierówności majątkowe.

Stwierdzony w Niemczech wysoki poziom nierówności zaprzecza potocznej opinii o dobrobycie społeczeństwa niemieckiego jako całości. W ich wyniki około 3/4 GD dysponuje majątkiem mniejszym niż wartość średnia. W przypadku około $50 \%$ niemieckich GD majątek w wielkościach bezwzględnych jest nawet niższy niż w Polsce. Należy więc negatywnie ocenić skuteczność realizowania celów społecznej gospodarki rynkowej w Niemczech.

\section{Literatura}

Atkinson A.B., Nierówności. Co da się zrobić?, Wydawnictwo Krytyki Politycznej, Warszawa 2017.

DB (2019) Household wealth and finances in Germany: results of the 2017 survey, Monthly Report, Deutsche Bundesbank, June 2019.

Deaton A., Wielka ucieczka. Zdrowie, bogactwo i źródła nierówności, PWN, Warszawa 2016. Dobrobyt społeczny, nierówności i sprawiedliwość dystrybutywna, S.M. Kot, A. Malanowski,

A. Węgrzecki (red.), Wydawnictwo Akademii Ekonomicznej w Krakowie, Kraków 2004.

ECB (2016), The Eurosystem Household Finance and Consumption Survey: Results from the second wave, Statistics Paper Series 18, Household Finance and Consumption Network, European Central Bank, 2016.

ECB (2017), The Household Finance and Consumption Survey. Wave 2. Statistical Tables, ECB, 2017.

Famielec J., Rola przedsiębiorczości w społecznej gospodarce rynkowej (wzorce Erharda i Euckena), [w:] Społeczne gospodarka rynkowa: Polska i integracja europejska, E. Mączyńska, P. Pysz (red.), PTE, Warszawa 2018.

Grejcz K., Żółkiewski Z., Household wealth in Poland: the results of a new survey of household finance, „Bank i Kredyt” 2017, nr 48(3).

Grejcz K., Żółkiewski Z., Majątek gospodarstw domowych w Polsce - wstępne wyniki, Prezentacja z Konferencji Naukowej Dtugoterminowe oszczędzanie, SGH, Warszawa 2016. Mączyńska E., Ordoliberalizm i społeczna gospodarka rynkowa jako podstawy inkluzywnego systemu społeczno-gospodarczego, [w:] Społeczne gospodarka rynkowa: Polska i integracja europejska, E. Mączyńska, P. Pysz (red.), PTE, Warszawa 2018.

Piketty T., Kapitał w XXI wieku, Wydawnictwo Krytyki Politycznej, Warszawa 2015. Stiglitz J.E., Cena nierówności, Wydawnictwo Krytyki Politycznej, Warszawa 2015. Therborn G., Nierówność, która zabija, PWN, Warszawa 2015.

Ustawa z dnia 2 kwietnia 1997 r., Konstytucja Rzeczypospolitej Polskiej (Dz.U. z 1997, nr 78, poz. 483).

Wilkinson R., Pickett K., Duch równości, Wydawnictwo Czarna Owca, Warszawa 2011.

Zasobność gospodarstw domowych w Polsce. Raport z pilotażowego badania 2016 r., NBP, Warszawa 2017. 